\title{
Titanium Production via Titanium Sulfide
}

\author{
R. O. Suzuki ${ }^{\mathrm{a}, *}$, Y. Yashima ${ }^{\mathrm{a}}$, N. Suzuki ${ }^{\mathrm{a}}$, E. Ahmadi ${ }^{\mathrm{a}}$,, S. Natsui ${ }^{\mathrm{a}, \mathrm{c}}$, T. Kikuchi $^{\mathrm{a}}$ \\ a: Hokkaido University, Sapporo, Japan, b: Universiti Sains Malaysia, Nibong Tebal, Malaysia, c: Tohoku \\ University, Sendai, Japan \\ *rsuzuki@eng.hokudai.ac.jp
}

\begin{abstract}
$\underline{\text { Abstract }}$
A new metallurgical process via titanium sulfide from ilmenite is proposed and experimentally approved: It consists of several stages; 1 ) The ilmenite ore is exposed to gaseous $\mathrm{CS}_{2}$ to selectively sulfurize to $\mathrm{FeS}$, which is wet-chemically removed. 2) The residual oxide is again exposed to $\mathrm{CS}_{2}$ to form $\mathrm{TiS}_{2} .3$ ) $\mathrm{TiS}_{2}$ is electrochemically reduced to metallic $\mathrm{Ti}$ using molten $\mathrm{CaCl}_{2}-\mathrm{CaS}$ as an application of OS process.

$\mathrm{TiFeO}_{3}$ was exposed to $\mathrm{Ar}-\mathrm{CS}_{2}$ mixed gas flow at $1173 \mathrm{~K}$ to form the mixture of $\mathrm{FeS}+\mathrm{TiO}_{2}$. $\mathrm{FeS}$ was easily separated by immersing in $\mathrm{H}_{2} \mathrm{SO}_{4}$ solution at $313 \mathrm{~K}$. After recovery of $\mathrm{TiO}_{2}$, it was converted completely to $\mathrm{TiS}_{2}$ by the second sulfurization with $\mathrm{CS}_{2}$. $\mathrm{TiS}_{2}$ could be reduced to Ti powder by calciothermic reduction and simulteneous electrolysis in a $\mathrm{CaS}-\mathrm{CaCl}_{2}$ melt for about 6 hours at $1173 \mathrm{~K}$ and $3.0 \mathrm{~V}$. The impurity decreased to a low level such as 0.021 mass $\% \mathrm{~S}$ due to very small solubility of $\mathrm{S}$ in a-Ti. However, 1.06 mass\%O remained because of wide solubility of oxygen in a-Ti and water contamination in initial $\mathrm{CaCl}_{2}$.
\end{abstract}

\section{Introduction}

Titanium dioxide converted from ilmenite (mainly $\mathrm{FeTiO}_{3}$ ) has been normally taken as the starting material both for Kroll process [1] or for newly developing refining processes such as FFC Cambridge process [2] and OS process [3]. In case of direct reduction from the oxide, the complete removal of oxygen from the obtained metallic Ti has not yet achieved although many researchers have challenged. The reasons of this oxygen contamination are thermodynamically wide solubility of oxygen in a-Ti and the technically insufficient oxygen removal from the reactors. Once the oxide is taken as the starting material of reduction, a fairly amount of oxygen still remains in the obtained Ti particles, although many operating parameters were optimized such as reaction temperature, time, applying voltage, gas environment, crucible, salt constitutions and their compositions, particle size, oxide phases, electrode materials and cell arrangements [4].

Kroll process removes oxygen from $\mathrm{TiO}_{2}$ once by conversion to $\mathrm{TiCl}_{4}$ and $\mathrm{CO} / \mathrm{CO}_{2}$ gas, and highly pure titanium metal is formed, because Ti does not dissolve $\mathrm{Mg}$ and $\mathrm{Cl}$, and because the distillation of $\mathrm{TiCl}_{4}$ is available to get the higher purity [1]. In analogy with Kroll process, the authors proposed utilization of sulfur: Unfortunately there is no natural resource of Ti sulfides, but $\mathrm{TiO}_{2}$ can be easily converted to $\mathrm{TiS}_{2}$ and $\mathrm{CO} / \mathrm{CO}_{2}$ gas when $\mathrm{CS}_{2}$ gas is used [5]. The reduction of $\mathrm{TiS}_{2}$ is expected as an application of FFC Cambridge process or OS process; the molten salt electrolysis of $\mathrm{TiS}_{2}$ in $\mathrm{CaCl}_{2}$ melt is applied to remove sulfur from the cathode as $\mathrm{CaS}$, which is exhausted out as $\mathrm{S}_{2}$ gas from the carbon anode [6,7]. The extracted $\mathrm{S}_{2}$ gas may be used to synthesis $\mathrm{CS}_{2}$ for $\mathrm{TiO}_{2}-\mathrm{TiS}_{2}$ conversion, but the simple mixture of carbon and $\mathrm{S}_{2}$ gas can be thermodymically used for sulfization of $\mathrm{TiO}_{2}$ [8]. This may correspond to chlorination process in Kroll process. Fig.1 shows the combinations of various reactions on Ti refining. 


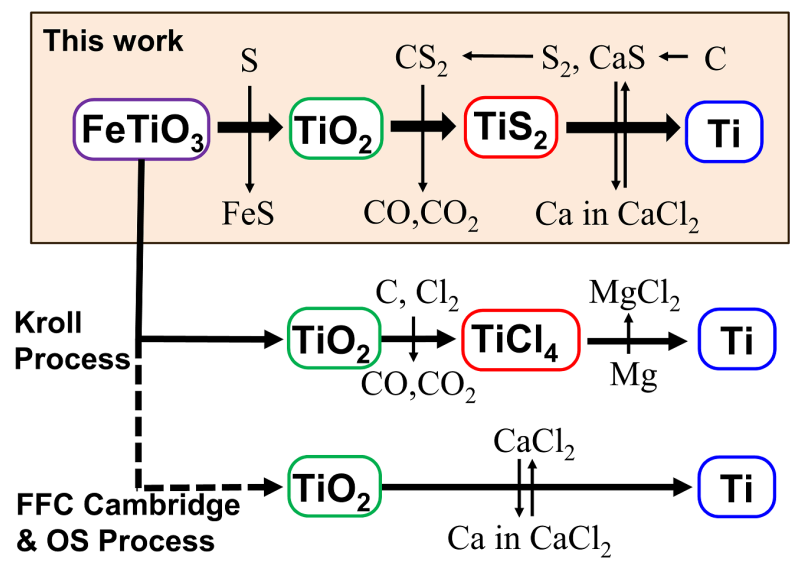

Fig. 1 Comparison of Ti preparation in Kroll process [1], oxide reduction processes such as FFC Cambridge process [2] and OS process [3] with this proposal using sulfur [6,7].

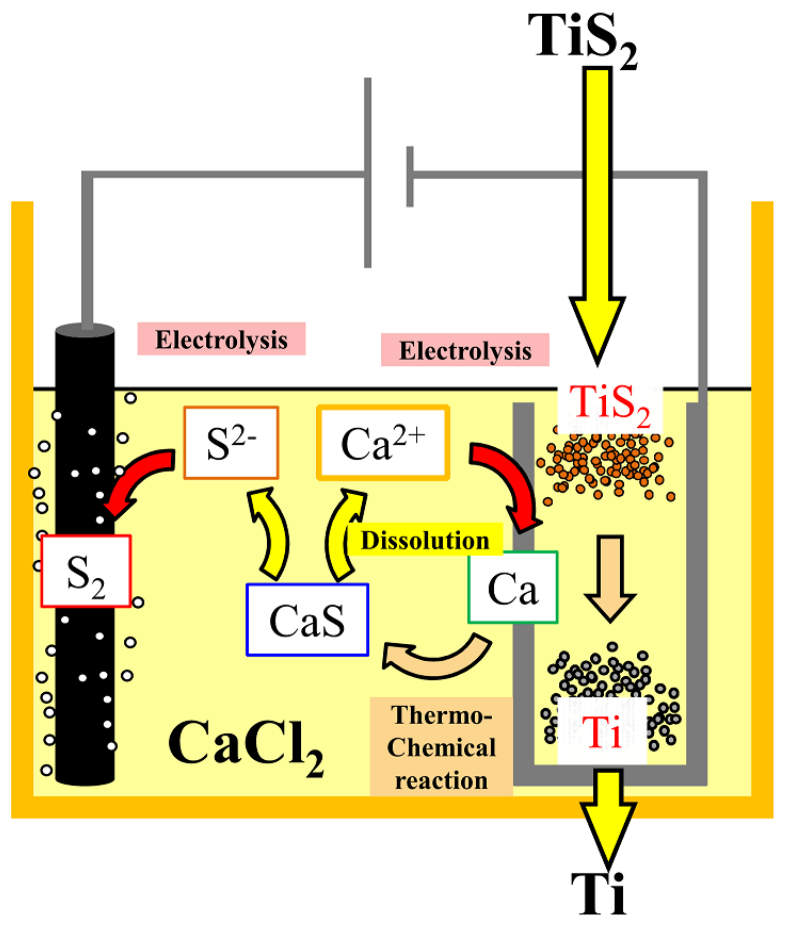

Fig. 2 Reactions of $\mathrm{TiS}_{2}$ reduction in molten $\mathrm{CaCl}_{2}[6,7]$.

Fig.2 illustrates the reactions in case of reduction of $\mathrm{TiS}_{2}$ in the molten $\mathrm{CaCl}_{2}$-CaS mixture [6,7]. About $1.9 \mathrm{~mol} \% \mathrm{CaS}$ can dissolve in the $\mathrm{CaCl}_{2}$ melt at $1173 \mathrm{~K}$ [9], and it decomposes to $\mathrm{Ca}^{2+}$ and $\mathrm{S}^{2-}$ as shown in eq.(1). By applying a higher cell voltage than the theoretical decomposition voltage (2.1-2.2V at $1173 \mathrm{~K}$ [8]), metallic Ca 
and $\mathrm{S}_{2}$ gas can be electrochemically precipitated on the cathode and anode surfaces, respectively, as expressed in eq.(2) and (3).

$$
\begin{aligned}
& \mathrm{CaS}=>\mathrm{Ca}^{2+}+\mathrm{S}^{2-} \\
& \mathrm{Ca}^{2+}+2 \mathrm{e}^{-}=>\mathrm{Ca} \text { (at cathode) } \\
& \mathrm{S}^{2-}=>1 / 2 \mathrm{~S}_{2}(\mathrm{~g})+2 \mathrm{e}^{-} \text {(at anode) }
\end{aligned}
$$

As considered in OS process [3,4], the deposited $\mathrm{Ca}$ from $\mathrm{CaCl}_{2}$ melt again dissolves into the bulk due to the metallic solubility of $\mathrm{Ca}$ (about a few mol\%). The dissolved $\mathrm{Ca}$ metal will be written here as $\underline{\mathrm{Ca}}$. It exists in the close vicinity of cathode, and thermochemically reacts with $\mathrm{TiS}_{2}$ particles that were filled inside the cathode basket.

$$
\begin{aligned}
& \mathrm{Ca}(\text { at cathode })=>\underline{\mathrm{Ca}}(\text { near cathode }) \\
& 2 \underline{\mathrm{Ca}}(\text { near cathode })+\mathrm{TiS}_{2}(\text { in cathodic basket })=>2 \mathrm{CaS}+\mathrm{Ti}
\end{aligned}
$$

The product Ti precipitates as solid particles inside the cathodic basket. The another product, CaS, will dissolve by following eq.(1). In this sequence, Ca circulates in the melt and does not go out from the reaction vessel. The deposited $\mathrm{S}_{2}(\mathrm{~g})$ in eq.(3) will leave from the anodic surface to the melt surface and diffuses to the gas phase over the melt. Finally it deposits on the wall of reaction vessel at the cooled parts, and it will be detected as amorphous sulfur or crystalline $\mathrm{S}_{8}(\mathrm{~s})$.

For synthesis of $\mathrm{TiCl}_{4}$ in Kroll process, chlorine gas should be safely circulated from the molten salt electrolysis without any leakage to the chlorination furnace. Because the melting point of $\mathrm{TiS}_{2}$ is higher than 1273 $\mathrm{K}$, the electrolysis and reduction can be operated as solid state of $\mathrm{TiS}_{2}$. A stockyard of solid $\mathrm{TiS}_{2}$ seems safer and more stable than a tank of liquid $\mathrm{TiCl}_{4}$, and the circulation of solid sulfur seems not so serious in factory processing. It is also noted that a plenty amount of sulfur can be served from copper smelting industries. Once sulfur can be set in the material cycle, it is not necessary to charge the additional sulfur as the principle of this proposal. Although the reduction of Ti sulfide by the other alkaline earth metals such as $\mathrm{Mg}$ is applicable, the recycling of $\mathrm{Mg}$ may cause another issue, while Ca recycling is ready in OS process [3,4].

The purpose of this work is to confirm the experimental quality of Ti obtained by our proposed process when $\mathrm{FeTiO}_{3}$ is taken as the starting material, although the fundamental reactions in molten salt electrolysis, (1)(5), have already been studied by starting from the commercial $\mathrm{TiS}_{2}$ powder [6,7]. Conversion from $\mathrm{TiO}_{2}$ to $\mathrm{TiS}_{2}$ was reported using $\mathrm{CS}_{2}$ gas, and this study takes this idea, although the starting oxide is $\mathrm{FeTiO}_{3}$.

\section{Material and experiments}

$0.2-1.0 \mathrm{~g} \mathrm{FeTiO}_{3}$ (Furuuchi Chemicals, $>99.9 \%$ ) was placed on the alumina or mullite boats and heated at $573-1473 \mathrm{~K}$ in Ar-CS 2 gas flow, as illustrated in Fig. 3. Gas flow rate $(20-100 \mathrm{~mL} / \mathrm{min} \mathrm{Ar})$ and reaction time (>1.8 ks) were chosen so that an excess amount of $\mathrm{CS}_{2}(>99.0 \%)$ gas was carried into the furnace. The reduction experiments using $600 \mathrm{~g} \mathrm{CaCl}_{2}$ (Kanto Chemicals, $>99.0 \%$ ) - $0.5 \mathrm{~mol} \% \mathrm{CaS}$ mixed salt in $\mathrm{MgO}$ crucible were conducted at $1173 \mathrm{~K}, 3.0 \mathrm{~V}$ using graphite anode (10 mm in diameter) and Ti basket-like cathode, as reported separately [6,7]. The morphology, phases and metallic impurities were measured by SEM, XRD and XRF, respectively. The residual oxygen and sulfur were studied using LECO TC-600 and CS-600 analyzers, respectively. 


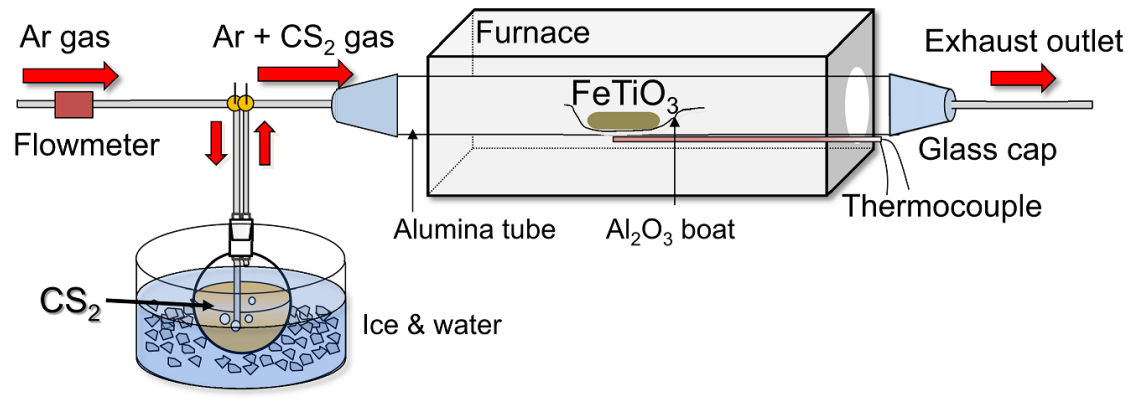

Fig. 3 Sulfurization in $\mathrm{CS}_{2}$ gas flow.

\section{Results and Discussion}

\subsection{Sulfurization of $\mathrm{FeTiO}_{3}$}

Powdery $\mathrm{FeTiO}_{3}$ contained a small amount of $\mathrm{TiO}_{2}$, as confirmed by XRD measurement (Fig.4). Volatile $\mathrm{CS}_{2}$ in ice-water was carried by $\mathrm{Ar}$ gas bubbling into the furnace, where the $\mathrm{FeTiO}_{3}$ powder was set on the ceramic boat. Fig. 4 shows also that the sample after sulfurization at $1073 \mathrm{~K}$ for 3.6 ks consisted of $\mathrm{Fe}_{1-x} \mathrm{~S}$ and $\mathrm{TiO}_{2}$. Selectively Fe was sulfurized by $\mathrm{CS}_{2}$ and no trace of Ti sulfides was found by XRD measurements.

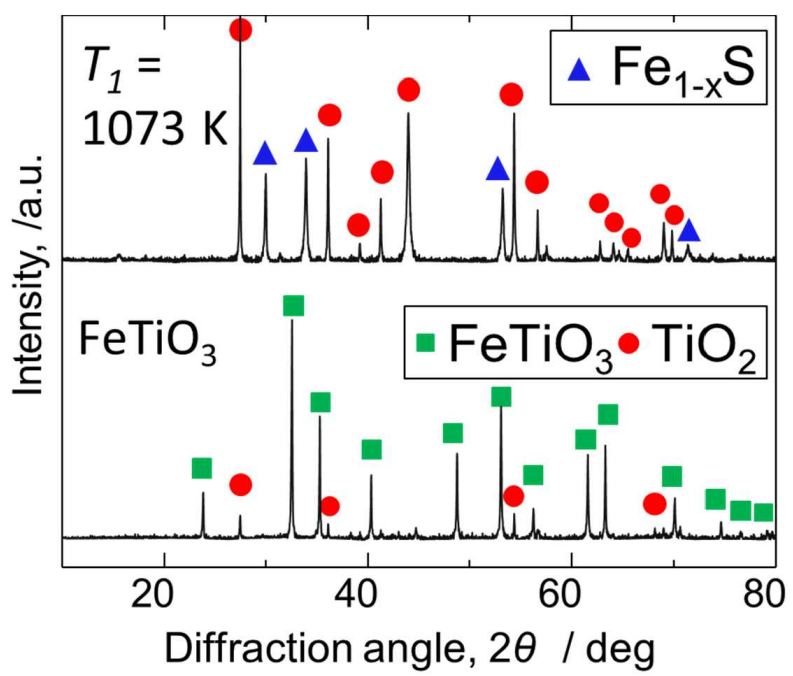

Fig. 4 XRD patterns of starting sample and the sample sulfurized in $\mathrm{CS}_{2}$ gas flow at $1073 \mathrm{~K}$. 


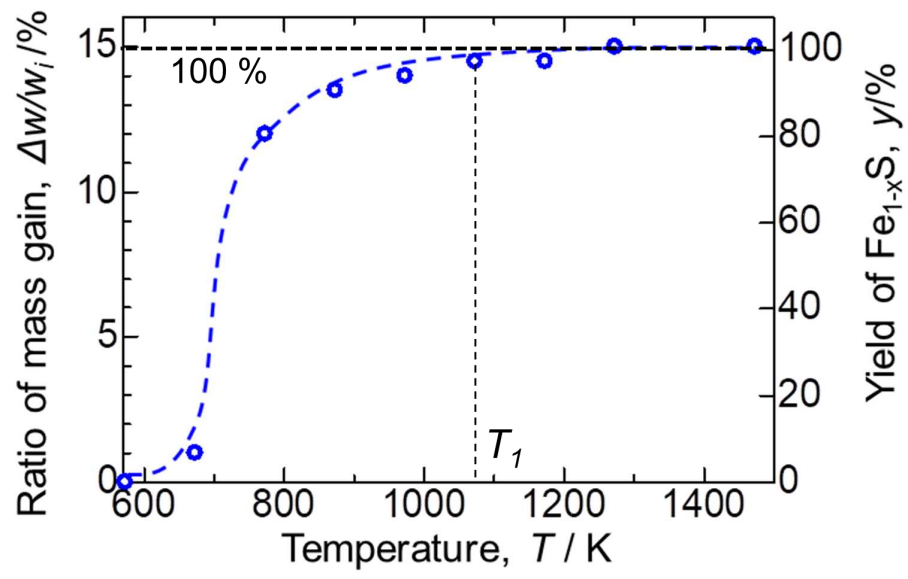

Fig.5 Mass change during sulfurization for $3.6 \mathrm{ks}$.

Fig. 5 shows the mass change during sulfurization by varying the holding temperature. When we assume that whole parts of initial sample consist of pure $\mathrm{FeTiO}_{3}$ and that this sample is converted into the stoichiometric $\mathrm{FeS}$ and $\mathrm{TiO}_{2}$, the conversion ratio of $\mathrm{FeTiO}_{3}$ to $\mathrm{FeS}$ is defined as "yield of $\mathrm{Fe}_{1-\mathrm{x}} \mathrm{S}$ ", $y$, as shown in Fig. 5. $y$ becomes $100 \%$ at $\mathrm{D} W / W_{i}=14.93 \%$, where the non-stoichiometry of $\mathrm{Fe}_{1-\mathrm{x}} \mathrm{S}, x=0.14$. Note that $x=0$ at $\mathrm{D} W / W_{i}=10.59 \%$. The sulfurization started at the temperature as low as $773 \mathrm{~K}$, and a steady value of $100 \%$ conversion was obtained above $1173 \mathrm{~K}$. The sample at $1473 \mathrm{~K}$ was partially melted because the melting point of $\mathrm{FeS}$ is $1465 \mathrm{~K}$ [8]. By changing the Ar gas flow rate, the concentration of $\mathrm{CS}_{2}$ in the mixed gas could be varied in the range of $25-34 \mathrm{vol} \%$. However, $\mathrm{D} W / W_{i}$ was in a small variation of $11.5-15 \%$ for $3.6 \mathrm{ks}$ at $1173 \mathrm{~K}$ and $\mathrm{Ti}$ sulfides were never found by XRD. Even after a long sulfurization such as $14.4 \mathrm{ks}$, no Ti sulfides were formed. The deposition of solid sulfur was found at the low temperature area of downstream. Therefore, the corresponding reaction of sulfurization can be shown as eq. (6) and/or (7).

$$
\begin{aligned}
& \mathrm{FeTiO}_{3}+1 / 2 \mathrm{CS}_{2}(\mathrm{~g})=\mathrm{TiO}_{2}+\mathrm{Fe}_{1-x} \mathrm{~S}+1 / 2 \mathrm{CO}_{2}(\mathrm{~g}) \\
& \mathrm{FeTiO}_{3}+\mathrm{CS}_{2}(\mathrm{~g})=\mathrm{TiO}_{2}+\mathrm{Fe}_{1-x} \mathrm{~S}+\mathrm{CO}(\mathrm{g})+1 / 2 \mathrm{~S}_{2}(\mathrm{~g})
\end{aligned}
$$

Before this experiments, the authors had expected a complete sulfurization as shown in eq.(8),

$$
\mathrm{FeTiO}_{3}+\mathrm{CS}_{2}(\mathrm{~g})=\mathrm{TiS}_{2}+\mathrm{Fe}_{1-x} \mathrm{~S}+\mathrm{CO}(\mathrm{g}) / \mathrm{CO}_{2}(\mathrm{~g})
$$

and these reactions corresponds to $\mathrm{D} W / W_{i}=31.77 \%$. Judging from these experimental results, $\mathrm{CS}_{2}(\mathrm{~g})$ sulfurizes $\mathrm{FeTiO}_{3}$ preferentially to form $\mathrm{Fe}_{1-x} \mathrm{~S}$, and rutile-type $\mathrm{TiO}_{2}$ remains as a by-product.

Thermodynamically these three reactions should proceed forward, although some data on the lower sulfides in Ti-S system are missing [8]. Therefore, the kinetic effect such as core-shell model is suspected that the converted FeS might cover the particle surface and prohibit further sulfurization.

\subsection{Leaching of $\mathrm{FeS}$ in $\mathrm{H}_{2} \mathrm{SO} 4$ solution}

In order to separate $\mathrm{Fe}$ from the metallic $\mathrm{Ti}$ in this proposal, it is necessary to remove Fe before electrolysis in the molten salt. Because the mixture of $\mathrm{FeS}$ and $\mathrm{TiO}_{2}$ was obtained after $\mathrm{CS}_{2}$ sulfurization, $\mathrm{FeS}$ 
removal was conducted in an acidic solution. $\mathrm{FeS}$ can dissolve quickly either in $1 \mathrm{M} \mathrm{HCl}$ or $1 \mathrm{M} \mathrm{H}_{2} \mathrm{SO}_{4}$ solutions, while $\mathrm{FeTiO}_{3}$ was hardly dissolved in these solutions at room temperature. The sample sulfurized at $1073 \mathrm{~K}$ for $14.4 \mathrm{ks}$ was leached in $1 \mathrm{M} \mathrm{HCl}$ solution for a day, and a fairly large amount of $\mathrm{FeS}$ remained. However, $1 \mathrm{M}$ $\mathrm{H}_{2} \mathrm{SO}_{4}$ solution could remove most of FeS phase at the same conditions as identified by XRD measurement (Fig.6). In addition, the background intensity of XRD pattern was very high before leaching because of $\mathrm{Fe}$ fluorescence X-ray under $\mathrm{Cu}-\mathrm{Ka}$ radiation. The residual $\mathrm{Fe}$ in the leached samples in $1 \mathrm{M} \mathrm{H}_{2} \mathrm{SO}_{4}$ solution was therefore examined by XRF analysis as shown in Fig.7.

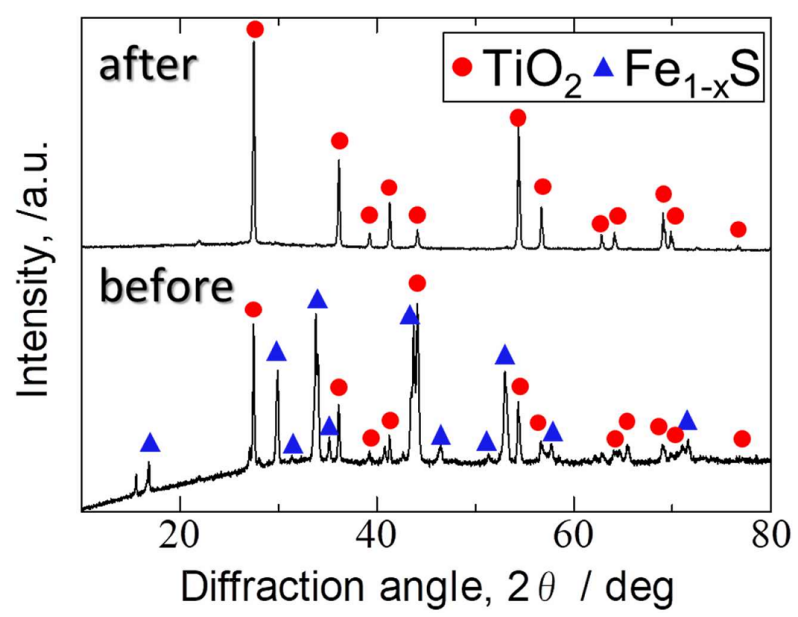

Fig. 6 Change of XRD patterns by $1 \mathrm{M} \mathrm{H}_{2} \mathrm{SO}_{4}$ leaching.

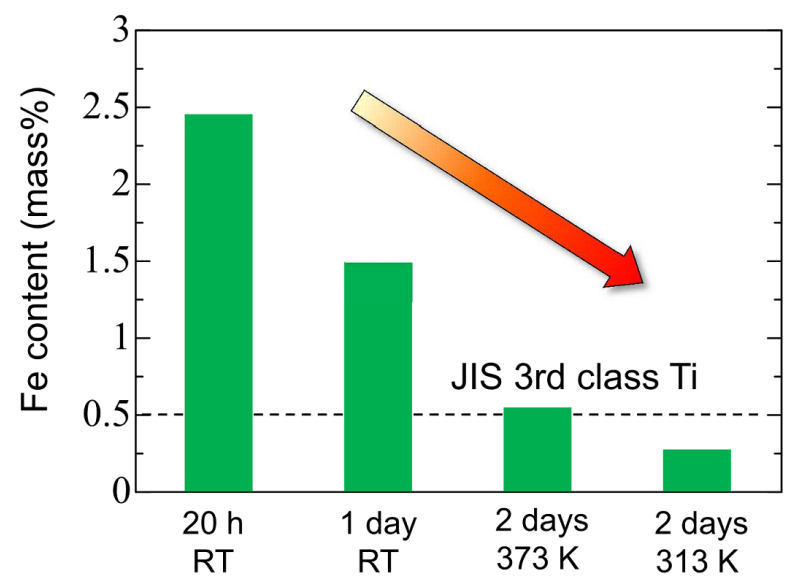

Fig. 7 Residual Fe after leaching in $1 \mathrm{M} \mathrm{H}_{2} \mathrm{SO}_{4}$.

Fe removal in $1 \mathrm{M} \mathrm{H}_{2} \mathrm{SO}_{4}$ solution could be conducted at room temperature and the heating did not enhance the $\mathrm{Fe}$ dissolution. It is noteworthy that a wet chemical process to remove $\mathrm{Fe}$ from $\mathrm{FeTiO}_{3}$ is normally operated above $473 \mathrm{~K}$ in a conc. $\mathrm{H}_{2} \mathrm{SO}_{4}$ for a several days. $\mathrm{FeS}$ removal in this study was effectively quick to 
promote Fe separation. As seen in Fig. 7, 0.28 mass\%Fe leached for $172.8 \mathrm{ks}$ at $313 \mathrm{~K}$ satisfied with the regulation for 3rd class of Japanese Industrial Standard (JIS) titanium. The residue in $1 \mathrm{M} \mathrm{H}_{2} \mathrm{SO}_{4}$ solution was coarse $\mathrm{TiO}_{2}$ particles with about $10 \mathrm{~mm}$ in diameter, although its surface was rough suitable for successive gas reaction.

\subsection{Secondary sulfurization by $\mathrm{CS}_{2}$ gas}

The $\mathrm{FeTiO}_{3}$ samples sulfurized at a certain temperature by $\mathrm{CS}_{2}$ gas flow for 14.4 ks were leached to form $\mathrm{TiO}_{2}$, which were again sulfurized at the same temperature in $\mathrm{CS}_{2}$ gas flow. $\mathrm{Ti}_{1.083} \mathrm{~S}_{2}, \mathrm{Ti}_{2.45} \mathrm{~S}_{4}$ and $\mathrm{Ti}_{3} \mathrm{~S}_{4}$ were identified at $1073 \mathrm{~K}, 1173-1273 \mathrm{~K}$ and 1373-1473K, respectively, by XRD.

Fig. 8 shows the mass gain of the samples during sulfurization. At the higher temperatures, the lower sulfides in the Ti-S binary system appeared, and the mass change became the smaller. A small amount of $\mathrm{SiO}_{2}$ and $\mathrm{Al}_{2} \mathrm{O}_{3}$ were detected at the high temperature samples, which may originate from the impurity in the initial $\mathrm{FeTiO}_{3}$, or from the unexpected reaction with the boats.

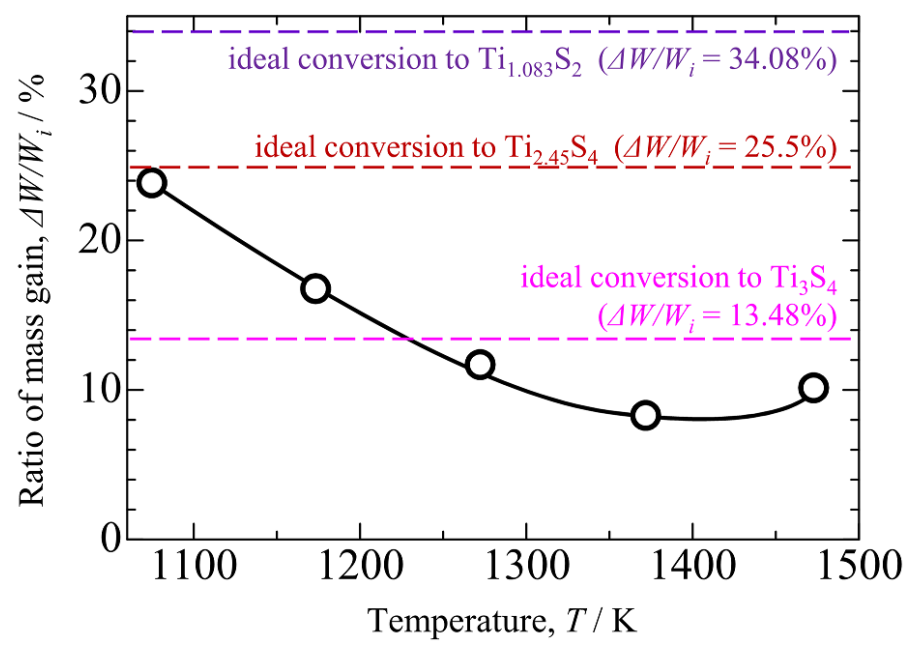

Fig. 8 Mass change during second sulfurization. 


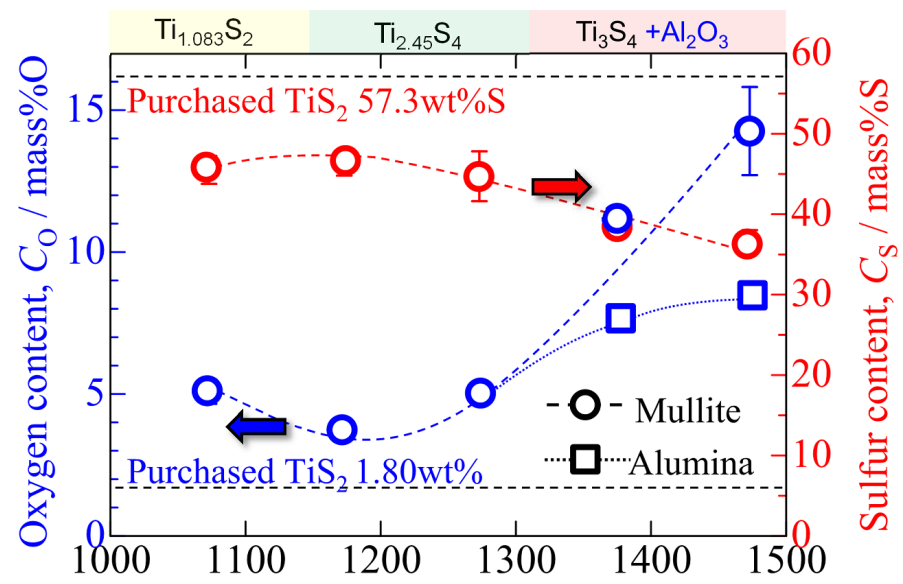

Temperature, $T / \mathrm{K}$

Fig. 9 Sulfur and oxygen analysis of secondary sulfurized samples on the ceramic boats.

Fig. 9 shows the analysis of oxygen and sulfur of the samples reacted for $14.4 \mathrm{ks}$. At the higher temperatures, the sulfur content decreased, and oxygen content increased significantly due to the reaction with the ceramic boats. Therefore, the conditions at $1173 \mathrm{~K}$ for $14.4 \mathrm{ks}$ were taken as an optimal condition for the subsequent study. The sample at these conditions contained 3.58 mass $\% \mathrm{O}$ and 46.3 mass $\% \mathrm{~S}$, although the lowest oxygen content is desired. It is also noteworthy that the greater concentration of sulfur needs the larger amount of electricity in electrochemical reduction of molten salt.

After optimizing the other sulfurization parameters, two samples were prepared with about $1.5 \mathrm{~g}$ from $\mathrm{FeTiO}_{3}$ at $1173 \mathrm{~K}$ for $43.2 \mathrm{ks}$ by feeding $\mathrm{CS}_{2}$ at $293 \mathrm{~K}$ in $\mathrm{Ar} 20 \mathrm{~mL} / \mathrm{min}$ flow. Their phase identification and impurity analysis are given in Table 1 . They were used in the reduction experiments as described later. It is noted that the sulfurized powder from the commercial $\mathrm{TiS}_{2}$ powder contained 0.43 mass $\% \mathrm{O}$ and $58.4 \mathrm{mass} \% \mathrm{~S}$ in the same conditions [6,7]. The oxygen level below 0.4 mass $\% \mathrm{O}$ were easily achieved at these conditions if $\mathrm{TiO}_{2}$ powder was taken as the starting material.

Fig. 10 shows the SEM morphology of the sample obtained after second sulfurization at $1073 \mathrm{~K}$ for $14.4 \mathrm{ks}$. The secondary grain size was about $10 \mathrm{~mm}$, and the primary particles were hexagonal plates of 100-200 $\mathrm{nm}$ size. This hexagonal thin plate-like character is common in transition metal chalcogenides $(\mathrm{Ch})$ with formula of $\mathrm{MCh}_{2}$. The "polytype" of Ti sulfides exist in Ti-S binary system, and they consist of multi-stacking layers of closed hexagonal packing and fcc packing. Therefore, the sulfur concentration is varied in a wide range. 

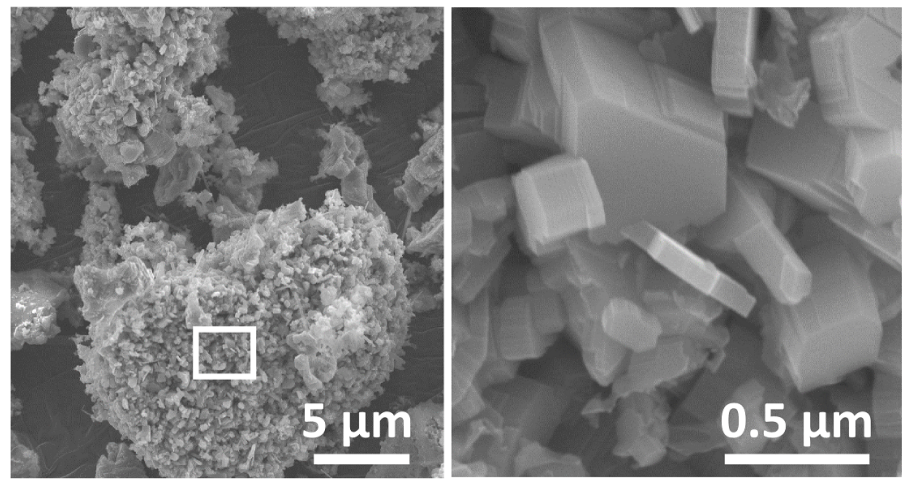

Fig. 10 SEM observation of the sample doubly sulfurized in $\mathrm{CS}_{2}$ gas flow at $1073 \mathrm{~K}$ for $14.4 \mathrm{ks}$.

\subsection{Electrolysis and Reduction in $\mathrm{CaCl}_{2}-\mathrm{CaS}$ melt}

The samples doubly sulfurized in $\mathrm{CS}_{2}$ gas $\left(\# \mathrm{~T}\right.$ and $\# \mathrm{U}$ ) were reduced at $1173 \mathrm{~K}$, at $3.0 \mathrm{~V}$ in $\mathrm{CaCl}_{2}$ $0.5 \mathrm{~mol} \% \mathrm{CaS}$. The electric charge $Q$ was served until $Q / Q_{0}=400 \%$, where $Q_{0}$ is defined as the theoretical charge to form the necessary amount of $\mathrm{Ca}$ by considering the reduction of pure and stoichiometric $\mathrm{TiS}_{2}$. As shown in Fig. 11, the current during the electrolysis with a constant voltage dropped at the initial stage, and approached to a constant value at $Q / Q_{0}=100 \%$. The measured current vibrated a little probably because of the gas bubbling at the anode. After cooling, yellow sulfur was deposited on the inner surface of cooled parts of reaction vessel. The solidified salt and the sample were removed from the Ti basket in the dilute acetic acid with a slight smell of sulfur. After several rinsing with water, ethanol and acetone, the sample was dried and analyzed as listed in Table 1.

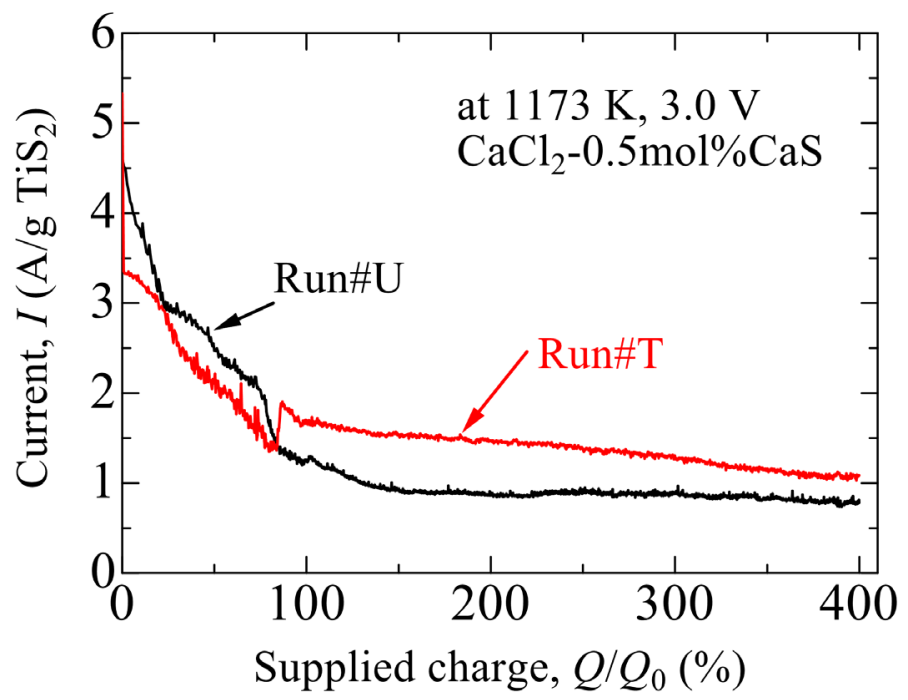

Fig. 11 Current behavior during electrolysis at $1073 \mathrm{~K}$. 
Table 1 Samples sulfurized from FeTiO3 and subsequently reduced in molten salt.

\begin{tabular}{|c|c|c|}
\hline Sample & $\# \mathrm{~T}$ & $\# \mathrm{R}$ \\
\hline Sulfurization by $\mathrm{CS}_{2}(\mathrm{~g})$ & \multicolumn{2}{|c|}{ Temperature of $\mathrm{CS}_{2}(\mathrm{liq})=293 \mathrm{~K}$. Sulfurized at $1173 \mathrm{~K}$ for $43.2 \mathrm{ks}$. } \\
\hline $\begin{array}{c}\text { Phases after } 2 \mathrm{nd} \\
\text { sulfurization } \\
\end{array}$ & $\begin{array}{l}\qquad \mathrm{Ti}_{2.45} \mathrm{~S}_{4} \text { and } \mathrm{Ti}_{7.07} \mathrm{~S}_{12} \\
\text { with a small amount of } \mathrm{TiO}_{2}\end{array}$ & $\begin{array}{l}\mathrm{Ti}_{2.45} \mathrm{~S}_{4} \text { and } \mathrm{Ti}_{7.07} \mathrm{~S}_{12} \\
\text { with a small amount of } \mathrm{TiO}_{2}\end{array}$ \\
\hline Impurity after 2 nd & 2.95 mass $\% O$ & 1.16 mass $\% O$ \\
\hline sulfurization & 50.8 mass $\% \mathrm{~S}$ & $58.4 \mathrm{mass} \% \mathrm{~S}$ \\
\hline Electrolysis & \multicolumn{2}{|c|}{ at $1173 \mathrm{~K}$ and $3.0 \mathrm{~V}$ in $\mathrm{CaCl}_{2}-0.5 \mathrm{mo} \% \mathrm{~S}, Q / Q_{0}=400 \%$} \\
\hline Phases after electrolysis & $\alpha$-Ti and small amounts of $\mathrm{TiO}+\mathrm{Ti}_{3} \mathrm{O}_{5}$ & $\alpha$-Ti and a small amount of TiC \\
\hline $\begin{array}{l}\text { Impurity after } \\
\text { electrolysis }\end{array}$ & $\begin{array}{l}1.38 \text { mass } \% \mathrm{O}, \\
0.053 \text { mass } \% \mathrm{~S} \\
0.34 \text { mass } \% \mathrm{C}\end{array}$ & $\begin{array}{c}1.06 \text { mass } \% O \\
0.021 \text { mass } \% \mathrm{~S} \\
2.04 \text { mass } \% \mathrm{C}\end{array}$ \\
\hline
\end{tabular}

Very low sulfur concentration reflects the non-soluble nature of sulfur in Ti. It proved that the present proposal can work from ilmenite, and that sulfur acts as the media to produce a high quality of metallic titanium with a very low sulfur concentration.

Carbon contamination might come from the graphite anode through the electrolysis of CO32- $[3,4]$. It is also possible that CS2 gas may be formed at the anode from the reaction of anodic graphite and S2-. In the used alignment for electrolysis, this CS2 gas can react with the obtained Ti to form TiC. These carbon contaminations can be improved by the cell modification for electrolysis.

Oxygen contamination may come from the residual oxygen in sulfurization and partially from the water in $\mathrm{CaCl} 2$ [4]. Thus some extra-tuning in operating conditions of sulfurization, iron removal and electrolysis is needed.
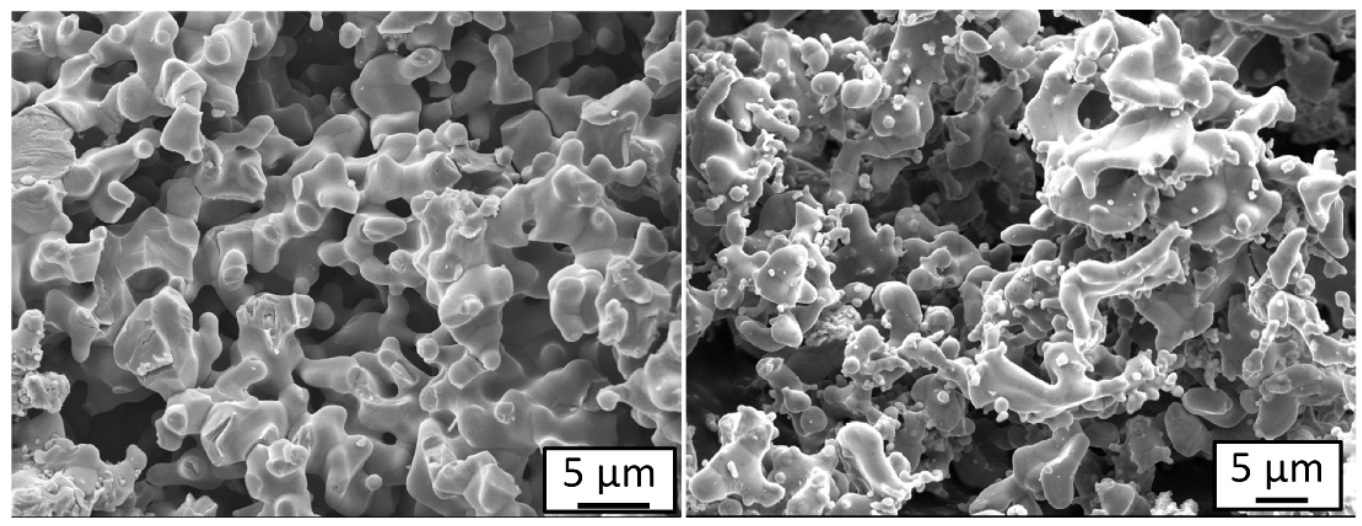
Fig. 12 SEM observation of the obtained titanium powder via TiS2 (a) from TiO2 and (b) from ilmenite.

Fig. 12 shows the comparison of titanium metallic particles obtained via TiS2. Fig.12(a) and (b) show the powders starting from the commercial $\mathrm{TiO} 2$ and from ilmenite, respectively, at the same electrochemical conditions. Reflecting the hexagonal plates of Ti sulfides, these Ti powders showed the porous morphology that some nodules jointed with a central spherical ball. This characteristic feature of Ti powder is expected suitable for 3D printer application.

\section{Conclusion}

Using CS2 gas evaporated at room temperature, ilmenite was easily sulfurized to the mixture of $\mathrm{Fe} 1-\mathrm{xS}$ and $\mathrm{TiO} 2$ (rutile). Fe1-xS was selectively removed by $1 \mathrm{M} \mathrm{H} 2 \mathrm{SO} 4$ solution even at room temperature to the suitable level of 0.5 mass $\% \mathrm{Fe}$ in Ti. Heating and violent stirring were not needed. After second sulfurization by CS2 gas, Ti sulfides lower than TiS2 were obtained and this mixture was electrochemically reduced in the molten $\mathrm{CaCl} 2$ $\mathrm{CaS}$ at $1173 \mathrm{~K}$. Successfully $\urcorner$-Ti was obtained and the residual sulfur in Ti was as low as $0.021 \mathrm{mass} \% \mathrm{~S}$. The by-product S2(gas) in this work should be served to synthesis CS2, which has already utilized in the chemical industry.

\section{Acknowledgements}

This work was financially supported by the Grants-in-Aid for Scientific Research (KAKENHI) Program under No.17H03434, by Japan Mining Industry Association, and by Innovative Structural Materials Association (ISMA)-NEDO.

\section{References}

[1] W. Kroll, J. Electrochem. Soc., 78 (1940) 35-47.

[2] G.Z. Chen, D.L. Fray and T.W. Farthing, Nature 407 (2000) 361-364.

[3] R.O. Suzuki, K. Teranuma and K. Ono, Metall. Mater. Trans. B 34 (2003) 287-295.

[4] H. Noguchi, S. Natsui, T. Kikuchi and R. O. Suzuki, Electrochemistry, 86(2) (2018) 82-87.

[5] M. Ota, S. Satoh, T. Kuzuya, S. Hirai, M. Kunii and A. Yamamoto, Acta Mater., 60 (20) (2012) 7232-7240.

[6] N. Suzuki, M. Tanaka, H. Noguchi, S. Natsui, T. Kikuchi and R. O. Suzuki, Mater. Trans., 58 [3] (2017) 367370.

[7] N. Suzuki, S. Natsui, T. Kikuchi and R. O. Suzuki, ECS Transactions, 75 [15] (2016) 507-515.

[8] A. Roine, et al., "HSC Chemistry, ver.8.0.8", Outotec Technologies, Poli, Finland (2014).

[9] T. Matsuzaki, R. O. Suzuki, S. Natsui, T. Kikuchi, M. Ueda, Mater. Trans., 60 [3] (2019) 386-390. 